\title{
Comment on identification with Taylor Rules: is it indeed impossible?
}

Citation for published version (APA):

Carrillo, J. A. (2008). Comment on identification with Taylor Rules: is it indeed impossible? METEOR, Maastricht University School of Business and Economics. METEOR Research Memorandum No. 034 https://doi.org/10.26481/umamet.2008034

Document status and date:

Published: 01/01/2008

DOI:

10.26481/umamet.2008034

Document Version:

Publisher's PDF, also known as Version of record

\section{Please check the document version of this publication:}

- A submitted manuscript is the version of the article upon submission and before peer-review. There can be important differences between the submitted version and the official published version of record.

People interested in the research are advised to contact the author for the final version of the publication, or visit the DOI to the publisher's website.

- The final author version and the galley proof are versions of the publication after peer review.

- The final published version features the final layout of the paper including the volume, issue and page numbers.

Link to publication

\footnotetext{
General rights rights.

- You may freely distribute the URL identifying the publication in the public portal. please follow below link for the End User Agreement:

www.umlib.nl/taverne-license

Take down policy

If you believe that this document breaches copyright please contact us at:

repository@maastrichtuniversity.nl

providing details and we will investigate your claim.
}

Copyright and moral rights for the publications made accessible in the public portal are retained by the authors and/or other copyright owners and it is a condition of accessing publications that users recognise and abide by the legal requirements associated with these

- Users may download and print one copy of any publication from the public portal for the purpose of private study or research.

- You may not further distribute the material or use it for any profit-making activity or commercial gain

If the publication is distributed under the terms of Article $25 \mathrm{fa}$ of the Dutch Copyright Act, indicated by the "Taverne" license above, 
Julio A. Carrillo

Comment on Identification with Taylor Rules: is it indeed impossible?

Extended version

$\mathrm{RM} / 08 / 034$

JEL code: C2, C15, E40, E52

\section{METE@R}

Maastricht research school of Economics of TEchnology and ORganizations

Universiteit Maastricht

Faculty of Economics and Business Administration

P.O. Box 616

NL - 6200 MD Maastricht

phone : ++31 433883830

fax $\quad$ :++31433884873 


\title{
Comment on Identification with Taylor Rules: is it indeed impossible? Extended version
}

\author{
Julio A. Carrillo* \\ Universiteit Maastricht
}

August, 2008

\begin{abstract}
Cochrane (2007) points out that the Taylor rule parameters in New-Keynesian models are not identified, and thus trying to estimate them through single-equation regressions is pointless. This paper shows in contrast that this observation holds only for economies that do not display inflation inertia or habit formation. These inherent features of aggregate data allow to correctly identify the parameters of the monetary policy rule by single-equation analysis.

Keywords: policy rule regression, identification, general equilibrium, forward and backward-looking models

JEL Class.: C2, C15, E40, E52
\end{abstract}

\section{Introduction}

The aim of this paper is to reconsider the usefulness of Taylor rule regressions conducted through singleequations. Monetary policy rules gained importance since Taylor (1993), where the federal funds rate is shown to react quite systematic to movements on inflation and output away their targets. This opened an entire debate about how active the central bank should be in order to achieve determinacy (i.e., ruling out sunspots or excessive fluctuations). Accordingly, it is understood that determinacy is reached when the inflation coefficient on the latent rule is greater than one. ${ }^{1}$ For the U.S. case, Clarida, Gali and Gertler (2000) claim to find such evidence only for the post-Volcker period (1979 onwards), which would

\footnotetext{
*Corresponding author: Department of Economics, Universiteit Maastricht, PoBox 616, MD6200 Maastricht, The Netherlands. Ph: +(31) 4338-83640. Fax: +(31) 4338-84150. Email: j.carrillo@algec.unimaas.nl. I would like to thank F. Blasques, B. Candelon, P. Fève, J. Muysken, and A. Korpos for helpful discussions and comments. All errors are of course my own.

${ }^{1}$ Of course, monetary modelers recognize that determinacy is a property of a system, not of a single parameter. See Bullard and Mitra (2002) for instance.
} 
explain the great moderation.

There are different criticisms to Taylor and Clarida et al., specially because they use a single-equation. ${ }^{2}$ Can we rule out the possibility that we are instead estimating a reduced form?, or that the aggregate dynamics of the economy come from an alternative observationally equivalent model?, or why not ensure identification by using the information of a whole DSGE model? These are valid questions, from which we have not yet converge to a unique answer.

But one of the most critical arguments is certainly provided by Cochrane (2007), who claims that the possibility of identifying the parameters of the Taylor rule simply vanishes when using single-equation estimations. Cochrane shows a sort of a "curse" of the Taylor principle: In a purely forward-looking model, the eigenvalues that make the system determinate (say, the "stabilizers") are irremediably lost in the equilibrium dynamics. The Taylor principle shows how the parameters of the interest rate rule are partly responsible for the size of the stabilizers eigenvalues; if the latter are lost, than any information to identify the parameters of the Taylor rule will be also lost. ${ }^{3}$ Since forward-looking behavior its nowadays crucial on New Keynesian models, Cochrane critique seems to nullified any evidence about the size of the inflation coefficient conducted trough single-equation analysis.

On the other hand, the framework used by Cochrane overlook an essential issue about the dynamics of inflation and output inherent to actual data, that is persistence. Do inflation inertia and output persistence contain any information that would help to identify the parameters of the Taylor rule (provided that the central bank behavior could indeed be described through this latent rule)? This is the main question of this paper, whose answer is yes! These two features of aggregate data can help to identify the parameters of the interest rate rule, at least partially, even using a single-equation approach. This

\footnotetext{
${ }^{2}$ See, for instance, Hetzel, 2000; Linde, 2002; Lubik and Schorfheide, 2004; Beyer and Farmer, 2004 and 2005 ; Carrillo and Fève, 2006

${ }^{3}$ Cochrane, section 4.3, highlight some hopes and constraints for the identification of the Taylor rule parameters within a full-information approach, but this new attempt rule out any single-equation method.
} 
result is already provided by purely backward-looking models (see Carare and Tchaidze 2005). The reason is explained by Mavroeidis (2005), who recalls that high-order dynamics (or some persistence) on the regressors (or instruments) is a necessary condition for the generic identification of a structural model.

In this paper, the emphasis is on the new generation of monetary models, i.e., with inertia on price setting and habit formation on consumption yielding a hybrid model. ${ }^{4}$ For comparisons purposes, I consider additionally pure forward-looking and backward-looking models. After simulations, a series of regressions are performed as to recover the parameters of the imposed Taylor rule within each model. The remainder is as follows: first, the models are presented; then, more details about the calibration, the Monte Carlo simulations, and the regressions are provided; finally, the results and some concluding remarks close the present analysis.

\section{Models}

\section{$1.1 \quad$ Hybrid model}

A model able to merge backward and forward temporal dimensions can be stated as:

$$
\begin{gathered}
y_{t}=c_{1} y_{t-1}+\left(1-c_{1}\right) E_{t} y_{t+1}-c_{3}\left(i_{t}-E_{t} \pi_{t+1}\right)+e_{b, t} \\
\pi_{t}=\kappa y_{t}+\gamma_{b} \pi_{t-1}+\gamma_{f} E_{t} \pi_{t+1}+e_{\pi, t} \\
i_{t}=a_{\pi} \pi_{t}+a_{y} y_{t}+e_{i, t} \\
e_{x, t}=\rho_{x} e_{x, t-1}+\sigma_{x} \nu_{x, t} \quad \text { for } \quad x \in\{b, \pi, i\}
\end{gathered}
$$

where $E_{t}$ is the expectation operator conditional to the information available at period $t ; y_{t}, \pi_{t}$, and $i_{t}$ represent output, inflation and the nominal interest rate, all as deviations from their steady state values; $e_{b}, e_{\pi}$, and $e_{i}$ are assumed to be correlated disturbances in the spirit of Smets and Wouters (2007), i.e., representing a interest rate spread shock, a cost push shock, and a monetary policy shock, respectively; the innovations $\nu$ are assumed to be i.i.d. with $\mathcal{N}(0,1)$, while $\sigma_{x}$ for $x \in\{b, \pi, i\}$ are positive constants

\footnotetext{
${ }^{4}$ See Christiano, Eichenbaum and Evans (2005), or Smets and Wouters (2007), among others.
} 
proportional to the variance of the correlated shocks .

The first two relations are the New-Keynesian versions of the IS and the Phillips curves. The former correspond to the specification provided in Smets and Wouters (2007), which denotes the presence of habit formation on consumption; the latter is the version presented in the seminal work of Galí and Gertler (1999) which includes inflation inertia trough the existence of backward-looking firms. Equation (3) is a Taylor rule that for simplicity is stated in a contemporaneous dimension.

The coefficients presented in equations (1) and (2) are functions of the deep parameters in the economy, ${ }^{5}$ which includes: $h \in[0,1]$ as the habit persistence coefficient, $\sigma>0$ as the non-negative inverse of the inter-temporal elasticity of substitution, $\omega \in[0,1]$ as the proportion of backward-looking firms in the economy, $\alpha \in[0,1]$ as the probability of a firm to do not re-optimize prices in the present period, and $\beta \in[0,1]$ as the subjective discount rate for future consumption. Accordingly, $c_{1}=\frac{h}{1+h} ; c_{3}=\frac{1-c_{1}}{\sigma(1+h)}$; $\kappa=\frac{(1-\omega)(1-\alpha)(1-\alpha \beta)}{\phi} ; \gamma_{b}=\frac{\omega}{\phi} ; \gamma_{f}=\frac{\alpha \beta}{\phi} ;$ and $\phi=\alpha+\omega[1-\alpha(1-\beta)]$.

\subsection{Forward-looking model}

An special case happens when consumers do not form any habit $(h=0)$ and there are no backwardlooking firms $(\omega=0)$. In such a case, this setup converges to a pure forward-looking model in the way commonly found on textbooks.

\subsection{The backward-looking-Rudebusch model}

Rudebusch (2001) considered a constrained-VAR on the variables cited above which entails a nice goodness of fit for the U.S. economy. In specific,

\footnotetext{
${ }^{5}$ The reader is advice to review the aforementioned papers for details on the environments faced by households and firms and the derivation of these relations.
} 


$$
\begin{aligned}
& y_{t}=y_{1} y_{t-1}+y_{2} y_{t-2}+y_{3}\left(\frac{1}{4} \sum_{j=1}^{4}\left(i_{t-j}-\pi_{t-j}\right)\right)+e_{b, t} \\
& \pi_{t}=\pi_{0} y_{t-1}+\pi_{1} \pi_{t-1}+\pi_{2} \pi_{t-2}+\pi_{3} \pi_{t-3}+\pi_{4} \pi_{t-4}+e_{\pi, t}
\end{aligned}
$$

The economy is finally closed with the policy rule (3) and the shocks given by (4). This is a similar setting to Carare and Tchaidze (2005), though the main difference is that here the Taylor rule is present in a contemporaneous dimension (eq. 3), and not in a backward-looking version, keeping the same grounds of comparison with the hybrid model. Notice that switch off the forward-looking terms in the hybrid model is not possible even by setting extreme values for the deep parameters of the model. For instance, if we consider total habit persistence $(h=1)$, we would have that $c_{1}=1 / 2$ and thus we will still have the expected future output present on equation (1). That is why, without loss of generality, I chose the Rudebusch constrained-VAR to represent the backward-looking model.

\section{Simulations}

\subsection{Calibration}

Let $\beta=0.99$, implying a steady state annualized real interest rate of $4 \% ; \sigma=1$, for a logarithmic utility for consumption; $\alpha=0.8$, which denotes an average duration for price changes of 5 quarters; $\omega=0.5$, implying half of firms are backward-looking (following the estimations of Galí and Gertler, 1999); the habit persistence parameter $h$ is set to 0.7 , lying in the range of available estimates based on aggregate data (see Christiano et al, 2005; Boivin and Giannoni, 2006; and Smets and Wouters, 2007). The parameters of the Taylor rule take the classical values found in the literature and considered in Taylor (1993), i.e. $a_{\pi}=1.5$ and $a_{y}=0.5$. The choice of these parameters ensure that the hybrid model equilibrium will be determinate, though we could also choose parameters to study the indeterminate case, but this goes beyond the scope of this analysis. For the backward-looking model, the calibration corresponds to the estimations of Rudebusch (2001), i.e., $y_{1}=1.17, y_{2}=-0.27, y_{3}=-0.09, \pi_{0}=0.15, \pi_{1}=0.67$, $\pi_{2}=-0.08, \pi_{3}=0.29$ and $\pi_{5}=0.12 .^{6}$ Without loss of generality, we add the correlated shocks to

\footnotetext{
${ }^{6}$ For the standard deviations of the estimated coefficients and details about the estimations procedure, see Rudebusch (2001).
} 
Rudebusch's equations, though he did not find any evidence of autocorrelated disturbances within his setting.

The nuisance parameters of the shock processes are set following Smets and Wouters $(2007)$, i.e., $\left(\rho_{b}, \sigma_{b}\right)=$ $(0.22,0.23),\left(\rho_{p}, \sigma_{p}\right)=(0.89,0.14)$, and $\left(\rho_{i}, \sigma_{i}\right)=(0.5,0.24) ;$ the first two couples corresponds to the estimates of these authors, while for the monetary policy shock I adopt their prior values as to consider a mild persistent disturbance as a reference point.

\subsection{Monte Carlo and policy rule regressions}

In order to asses the ability of the single-equation approach to identify the parameters of the policy rule, the three models presented above are simulated within a Monte Carlo exercise, where 10,000 samples of 500 observations each one are generated. In every sample, a series of estimations are conducted, from which the OLS estimator, and two IV estimators with different instruments are put in place. ${ }^{7}$ The choose of the instruments follows from the common practice of the Taylor rule regression, where the lagged values of the regressors are taken; in this case, the first set of instruments is formed by $Z_{1, t}=\left(\pi_{t-1}, y_{t-1}\right)$, while the second denotes $Z_{2, t}=\left(\pi_{t-1}, \pi_{t-2}\right)$. The reasons behind the difference between $Z_{1, t}$ and $Z_{2, t}$ is to corroborate the robustness of the estimations and to elucidate the added value that may appear from considering two stochastic processes (like in $\left.Z_{1, t}\right)$, instead of one $\left(Z_{2, t}\right)$, as the relevant information to identify the Taylor rule parameters. ${ }^{8}$ Along the 10,000 regressions for each estimation technique, a density function is computed through a gaussian kernel. The mean of that distribution will tell us whether or not each estimation method is able to recover the Taylor rule parameters.

One important observation is that the single-equation approach is not spared from biases whenever the monetary shock inserted in the Taylor rule present some degree of persistence, at least for the hybrid and

\footnotetext{
${ }^{7}$ Clarida et al. (2000) use GMM estimation, with a set of predetermined instruments. Here we use the simplest GMM possible, with only 2 instruments to identify 2 Taylor rule parameters.

${ }^{8}$ There were also considered other set of instruments as $\left(i_{t-1}, y_{t-1}\right),\left(i_{t-1}, \pi_{t-1}\right),\left(y_{t-1}, y_{t-2}\right)$, or $\left(i_{t-1}, i_{t-2}\right)$. The results were invariant about the added value that the sequence of two different variables may provide over a sequence of one single variable.
} 
forward-looking model. This is because on the hybrid model the equilibrium dynamics of the economy imply that $z_{t}=\sum_{k \in\{b, \pi, i\}} z_{k} e_{k, t}$, for $z_{t} \in\left\{\pi_{t}, y_{t}\right\}$, where $z_{k}$ is a function of the deep parameters of the model. Therefore, the OLS-estimator will be biased as long as the monetary innovation is present, since $E\left(e_{i, t} z_{t}\right)$ will be different from zero. For the IV-estimators, the orthogonality condition is not verified as long as $E\left(e_{i, t} z_{t-1}\right) \neq 0$, which is the case whenever $\left\|\rho_{i}\right\|>0$. In the case of the backward-looking model, in contrast, all estimations techniques are unbiased by construction. ${ }^{9}$

To asses the importance and size of these biases, at least for the IV-estimators of the hybrid and forwardlooking models, two series of simulations can be confronted: (I), where the innovations are not correlated (all the $\rho$ 's equal zero), and (II) where serial correlation is present. For the latter case, we can still consider two subcases: (II.i) when only $a_{\pi}$ and $a_{y}$ are estimated; and (II.ii), using the Hildreth-Liu method to estimate $\rho_{i}$ along with the parameters of the Taylor rule.

\section{Results}

The results are stated in table 1. The estimated densities for cases (I) and (II.i) are displayed in figure 1, while case (II.ii) is depicted on figure 2. One observation that will hold for any model is that the OLS-estimations are characterized by at least equal or narrower distributions than the ones of the IV-estimations, which denotes a superiority in estimation precision; Though, as explained above, the OLS-estimators will be systematically biased for the hybrid and forward-looking models.

Forward-looking model. In this case, we can see directly that the striking observation of Cochrane (2007) holds in any single regression for this model. Indeed, no single estimation is able to recover the true parameters of the Taylor rule, in terms of the mean of the estimated densities, independently of whether shocks display serial correlation or not. In all cases, the estimations of the forward-looking model yield

\footnotetext{
${ }^{9}$ Consider for example a simplified version of the Rudebusch model:

$$
\begin{aligned}
y_{t} & =y_{1} y_{t-1}-i_{t-1} \\
i_{t} & =a_{y} y_{t}+e_{i, t}
\end{aligned}
$$

and $e_{i, t}$ following an $\mathrm{AR}(1)$ process as in (4). Then we can express output as $y_{t}=\left(\rho_{i}+y_{1}-a_{y}\right) y_{t-1}-\rho_{i}\left(y_{1}-a_{y}\right) y_{t-2}-$ $\sigma_{i} \nu_{i, t-1}$. Therefore $E\left(e_{i, t} y_{t}\right)=0$, and the OLS-estimator for the coefficient $a_{y}$ is unbiased.
} 
a mean that is less than one for $a_{\pi}$ and negative for $a_{y}$.

Hybrid model. Here we find, in contrast, very interesting results. In the case of no serial correlation (panel b.1 and b.2 of figure 1, and rows 4-6 on table 1), the OLS-estimation shows a slightly bias of 0.05 point estimates, since the mean values for $a_{\pi}$ and $a_{y}$ are 1.45 and 0.45 , respectively; the bias is reduced by one point estimate using the instrument set $Z_{2, t}$, but the standard deviations increase substantially. In contrast, the IV- $Z_{1, t}$ estimations display no bias and much more narrow confidence intervals for the estimated coefficients than $Z_{2, t}$. The unbiased estimates, at least for $Z_{1, t}$, are not surprising, since in the absence of correlated shocks, any lagged predetermined instrument is a valid instrument.

Assuming no serial correlation is, however, not very realistic. For instance, some authors attribute the sizable inertia of the interest rate in real data to very persistent monetary shocks. ${ }^{10} \mathrm{~A}$ persistent deviation from the latent rule may elicit any contingent event that is too hard to model within an interest rate rule, for which the central bank has to respond in a no systematic way. ${ }^{11}$ Therefore, we are interested in the estimations of the hybrid model when allowing serial correlation on all disturbances. In this case (displayed on panels b.3 and b.4 of figure 1 and rows 13-15 on table 1), we expect all estimations to present a certain bias, as explained in the preceding section. It is indeed the case for the OLS and IV- $Z_{1, t}$ estimations, but surprisingly, this is not true when using $Z_{2, t}$, for which we find no bias and decently narrow confidence intervals.

One might argue this is the result of considering a mild persistent monetary shock $\left(\rho_{i}=0.5\right)$, since the bias is expected to increase with higher values of $\rho_{i}$. But if we re-compute all the estimations with a $\rho_{i}=0.9$, the results are somehow unchanged. Indeed, in this special case, not shown on the table, ${ }^{12}$ we find bigger biases under OLS and IV- $Z_{1, t}$, with mean values of $a_{\pi}=1.25,1.20$ and $a_{y}=0.25,0.20$, respectively; whereas for $Z_{2, t}=\left(\pi_{t-1}, \pi_{t-2}\right)$ we still find unbiased mean values. A second explanation

\footnotetext{
${ }^{10}$ See Rudebusch (2006), or Carrillo, Fève and Matheron (2007).

${ }^{11}$ Like financial crises, credit crunches, commodities price instability or liquidity squeezes, just as our recent experience.

${ }^{12}$ The results of this and the next experiments are available under request.
} 
comes from the fact that inflation is highly persistent in the present setting $\left(\rho_{\pi}=0.89\right)$, which somehow may reduce the expected bias of the estimation procedure. ${ }^{13}$ In order to corroborate this fact, one can redo all the estimations with output as the most persistent instrument, by just inverting the values of $\rho$ from the former calibration, i.e. with $\rho_{b}=0.89$ and $\rho_{\pi}=0.22$. In this case, the bias of $Z_{1, t}$ disappears while the confidence intervals become narrow; for $Z_{2, t}$ there is an insignificant bias but much more wider confidence intervals. This gives an important guidance for the estimation of Taylor rules: choosing very persistent instruments may reduce the bias of single-equation estimations. This turns out to be important because inflation and output do display a high degree of sluggishness in actual data.

One can be also interested in whether we could also identify the persistence parameter of the monetary policy shocks and improve the estimations. Using the Hildreth-Liu method for serially correlated errors in the regression equation (panel b.1, b.2 and b.3 in figure 2, and bottom of table 1), we can see that the mean estimates of $a_{\pi}$ and $a_{y}$ are not so different than before, while only the OLS estimations are able to recover the true value of $\rho_{i}$. The estimates of the latter using $Z_{1, t}$ or $Z_{2, t}$ or not so precise, as the distribution densities are wider, and even bimodal for $Z_{2, t}$.

Backward-looking model. In what respect for this setting, the estimation results are quite compact: all estimations within all scenarios are unbiased and with quite similar densities in general. The latter verifies the results of Carare and Tchaidze (2005) and reinforce the observation that, in order to correctly identify the structural parameters of the Taylor rule, high-order dynamics in the regressors or instruments is a necessary condition.

\footnotetext{
${ }^{13}$ For instance, using IV $-Z_{2, t}$, we can express the probabilistic limit of the estimator $\widehat{a_{\pi}}$ as: $a_{\pi}+c\left(E\left(e_{i, t} \pi_{t-2}\right) E\left(y_{t} \pi_{t-1}\right)-\right.$ $\left.E\left(e_{i, t} \pi_{t-1}\right) E\left(y_{t} \pi_{t-2}\right)\right)$, where $c$ is a constant. If $\pi_{t}$ is highly persistent, it may be the case that the two terms conforming the bias simply vanish.
} 


\section{Conclusions}

The present analysis offers a hope for the identification of the Taylor rule parameters through singleequation estimations, a practice that became popular since the seminal work of Clarida et. al (2000). We have pointed out that the observation of Cochrane (2007), in what identification through singleequations is hopeless, applies only to model economies that do not display inflation inertia and output persistence, which are inherent characteristics of aggregate data in our economies. The results shown here are an illustration of the necessity of having high-order dynamics in the regressors or instruments as to correctly identify the policy rule parameters. One further observation is that instruments that are highly persistent may also help to minimize the bias which is inherent in the estimations procedures described here, whenever serial correlation is present on the policy rule. Of course, the present analysis relies on a strong assumption that is still the issue of several ongoing debates, which impose the Taylor rule as indeed the true, latent rule that describes the central bank policymaking.

\section{References}

1. Beyer, A., Farmer, R., 2004. On the indeterminacy of new-keynesian economics. Working Paper 323, European Central Bank.

2. Beyer, A., Farmer, R., 2005. Testing for indeterminacy: an application to U.S. monetary policy: Comment on paper by Thomas Lubik and F. Schorfheide. American Economic Review, 97, pp. 524-529.

3. Boivin, J., Giannoni, M.P., 2006. Has monetary policy become more effective? Review of Economics and Statistics, 88, pp. 445-462.

4. Bullard, J., Mitra, K., 2002. Learning about monetary policy rules. Journal of Monetary Economics, 49, pp. 1105-1129.

5. Carare, A., Tchaidze, R., 2005. The use and abuse of Taylor rules: How precisely can we estimate them? IMF working paper WP/05/148. 
6. Carrillo, J. A., Fève, P., 2006. Some perils of policy rule regression: the Taylor rule revisited. IDEI working paper.

7. Carrillo, J. A., Matheron, J., Fève, P., 2007. Monetary policy inertia or persistent shocks: A DSGE Analysis. International Journal of Central Banking, 3, pp. 1-38.

8. Christiano, L.J., Eichenbaum, M., Evans, C.L., 2005. Nominal rigidities and the dynamic effects of a shock to monetary policy. Journal of Political Economy, 113, pp. 1-45.

9. Clarida, R., Galí, J., Gertler, M., 2000. Monetary Policy Rules and Macroeconomic Stability: Evidence and Some Theory. Quarterly Journal of Economics, 115, pp. 147-180.

10. Cochrane, J. H., 2007. Identification with Taylor rules: A critical review. NBER Working Paper No. 13410 .

11. Galí, J., Gertler, M., 1999. Inflation Dynamics: A Structural Econometric Analysis. Journal of Monetary Economics, 44, pp. 195-222.

12. Hetzel, R.L., 2000. The Taylor Rule: Is it a Useful Guide to Understanding Monetary Policy? Federal Reserve Bank of Richmond, Economic Quarterly, 86, pp. 1-33.

13. Linde, J., 2002. Estimating New-Keynesian Phillips Curves: A Full Information Maximum Likelihood Approach. Working Paper Series 129, Sveriges Riksbank.

14. Lubik, T., Schorfheide, F., 2004. Testing for Indeterminacy: An Application to US Monetary Policy. American Economic Review, 94, pp. 190-217.

15. Mavroeidis, S., 2005. Identification issues in forward-looking models estimated by GMM, with an application to the Phillips Curve. Journal of Money, Credit, and Banking, 37, pp. 421-448.

16. Rudebusch, G.D., 2001. Is the Fed too timid? Monetary policy in an uncertain world. The Review of Economics and Statistics, 83, pp. 203-217. 
17. Rudebusch, G.D., 2006. Monetary policy inertia: Fact or fiction? International Journal of Central Banking, 2, pp. 85-136.

18. Smets, F., Wouters, R., 2007. Shocks and frictions in U.S. business cycles: A Bayesian DSGE approach. American Economic Review, 97, pp. 586-606.

19. Taylor, J.B., 1993. Discretion versus policy rules in practice. Carnegie-Rochester Conference Series on Public Policy, 39, pp. 195-214. 
Figure 1: Taylor regression, estimated coefficients densities
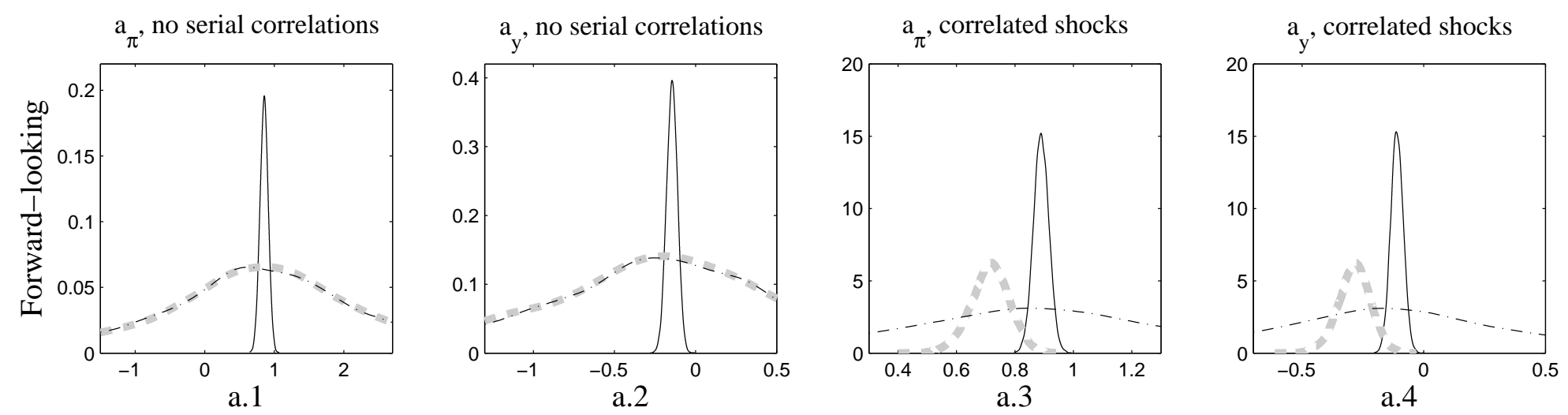

$\rightleftarrows$
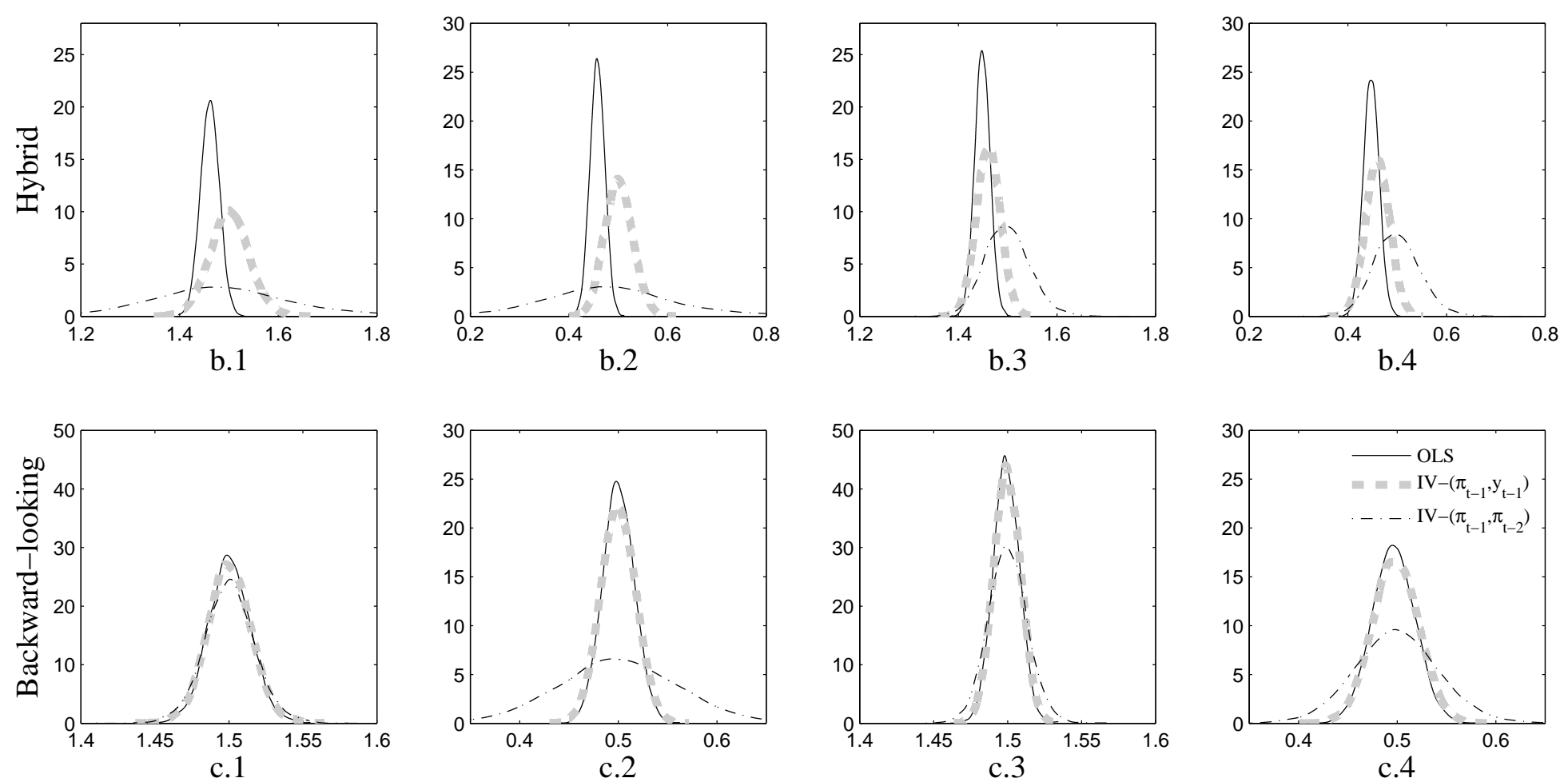
Figure 2: Taylor regression, using the Hildreth-Liu method
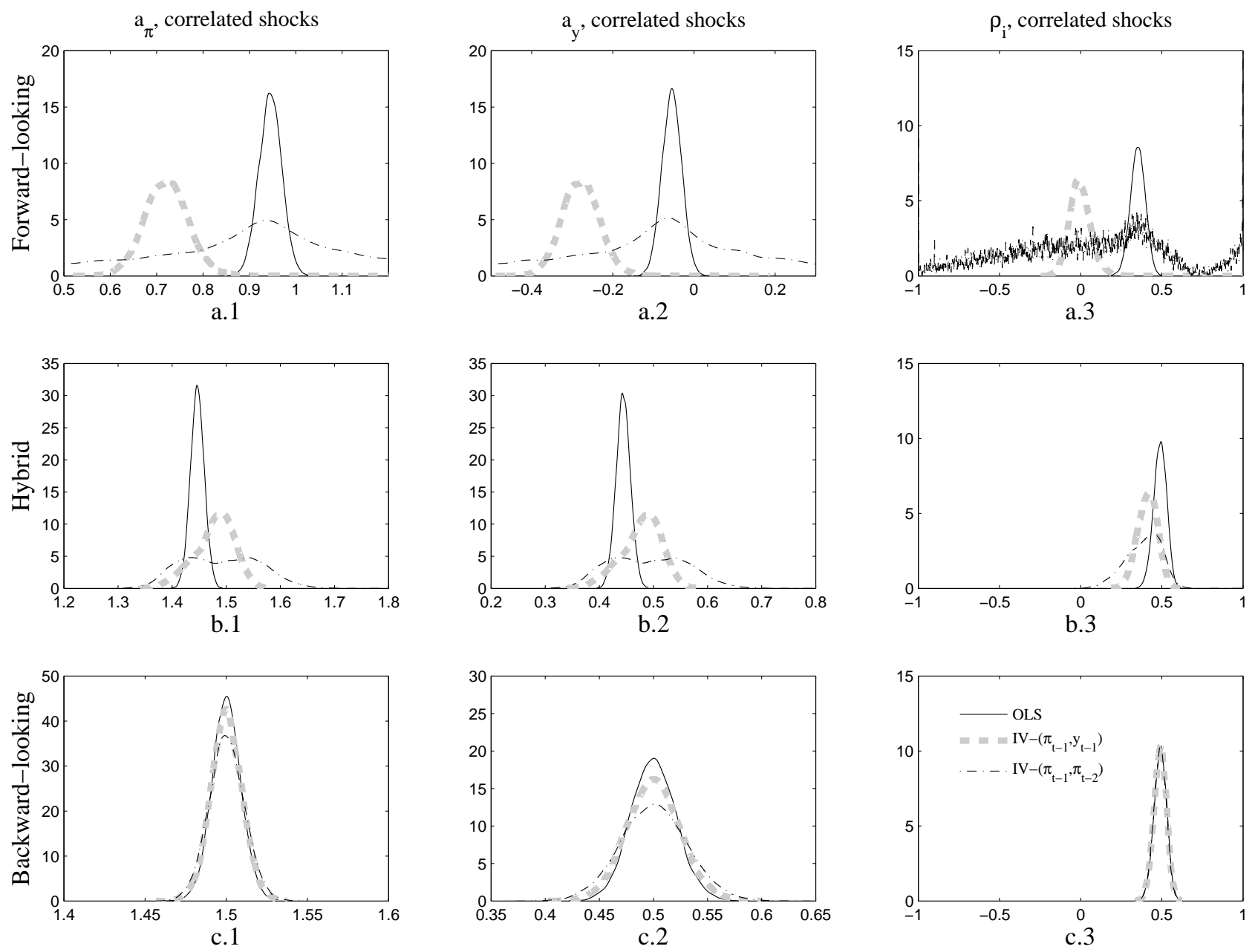
Table 1. Mean and standard deviations from estimated densities

\begin{tabular}{|c|c|c|c|c|c|c|c|}
\hline & & \multicolumn{3}{|c|}{$\begin{array}{c}\text { Mean } \\
\text { (St. Deviation) }\end{array}$} & \multicolumn{3}{|c|}{$90 \%$ confidence intervals } \\
\hline & & $a_{\pi}$ & $a_{y}$ & $\rho_{i}$ & $a_{\pi}$ & $a_{y}$ & $\rho_{i}$ \\
\hline \multicolumn{8}{|l|}{ No serial correlation } \\
\hline \multirow{3}{*}{ Forward-looking } & OLS & $\begin{array}{l}0.85 \\
(0.06)\end{array}$ & $\begin{array}{l}-0.15 \\
(0.03)\end{array}$ & $\overline{(-)}$ & {$[0.76,0.95]$} & {$[-0.20,-0.09]$} & {$[-]$} \\
\hline & $\operatorname{IV}-\left(\pi_{t-1}, y_{t-1}\right)$ & $\begin{array}{c}0.98 \\
(19.87)\end{array}$ & $\begin{array}{l}-0.06 \\
(13.15)\end{array}$ & $\overline{(-)}$ & {$[-7.03,8.77]$} & {$[-4.68,4.57]$} & {$[-]$} \\
\hline & $\operatorname{IV}-\left(\pi_{t-1}, \pi_{t-2}\right)$ & $\begin{array}{c}0.94 \\
(20.91)\end{array}$ & $\begin{array}{l}-0.12 \\
(13.24)\end{array}$ & $\frac{-}{(-)}$ & {$[-7.91,9.24]$} & {$[-5.10,5.01]$} & {$[-]$} \\
\hline \multirow{3}{*}{ Hybrid } & OLS & $\begin{array}{l}1.46 \\
(0.02)\end{array}$ & $\begin{array}{l}0.46 \\
(0.02)\end{array}$ & $\overline{(-)}$ & {$[1.43,1.49]$} & {$[0.43,0.48]$} & {$[-]$} \\
\hline & $\operatorname{IV}-\left(\pi_{t-1}, y_{t-1}\right)$ & $\begin{array}{l}1.50 \\
(0.04)\end{array}$ & $\begin{array}{l}0.50 \\
(0.03)\end{array}$ & $\overline{(-)}$ & {$[1.44,1.57]$} & {$[0.45,0.55]$} & {$[-]$} \\
\hline & $\mathrm{IV}-\left(\pi_{t-1}, \pi_{t-2}\right)$ & $\begin{array}{l}1.47 \\
(1.41)\end{array}$ & $\begin{array}{l}0.47 \\
(1.48)\end{array}$ & $\overline{(-)}$ & {$[1.20,1.79]$} & {$[0.21,0.75]$} & {$[-]$} \\
\hline \multirow{3}{*}{ Backward-looking } & OLS & $\begin{array}{l}1.50 \\
(0.01)\end{array}$ & $\begin{array}{l}0.50 \\
(0.02)\end{array}$ & $\overline{(-)}$ & {$[1.48,1.52]$} & {$[0.47,0.53]$} & {$[-]$} \\
\hline & $\mathrm{IV}-\left(\pi_{t-1}, y_{t-1}\right)$ & $\begin{array}{l}1.50 \\
(0.02)\end{array}$ & $\begin{array}{l}0.50 \\
(0.02)\end{array}$ & $\overline{(-)}$ & {$[1.48,1.53]$} & {$[0.47,0.53]$} & {$[-]$} \\
\hline & $\mathrm{IV}-\left(\pi_{t-1}, \pi_{t-2}\right)$ & $\begin{array}{l}1.50 \\
(0.02)\end{array}$ & $\begin{array}{l}0.50 \\
(0.06)\end{array}$ & $(-)$ & {$[1.47,1.53]$} & {$[0.40,0.60]$} & {$[-]$} \\
\hline \multicolumn{8}{|l|}{ Serial correlation } \\
\hline \multirow{3}{*}{ Forward-looking } & OLS & $\begin{array}{l}0.89 \\
(0.03)\end{array}$ & $\begin{array}{l}-0.11 \\
(0.03)\end{array}$ & $\overline{(-)}$ & {$[0.85,0.93]$} & {$[-0.15,-0.07]$} & {$[-]$} \\
\hline & $\operatorname{IV}-\left(\pi_{t-1}, y_{t-1}\right)$ & $\begin{array}{l}0.71 \\
(0.07)\end{array}$ & $\begin{array}{l}-0.29 \\
(0.07)\end{array}$ & $(-)$ & {$[0.60,0.82]$} & {$[-0.40,-0.18]$} & {$[-]$} \\
\hline & $\mathrm{IV}-\left(\pi_{t-1}, \pi_{t-2}\right)$ & $\begin{array}{l}0.95 \\
(12.49)\end{array}$ & $\begin{array}{l}-0.09 \\
(20.78)\end{array}$ & $\frac{-}{(-)}$ & {$[-2.45,4.10]$} & {$[-3.51,3.02]$} & {$[-]$} \\
\hline \multirow{3}{*}{ Hybrid } & OLS & $\begin{array}{l}1.45 \\
(0.02)\end{array}$ & $\begin{array}{l}0.45 \\
(0.02)\end{array}$ & $\frac{-}{(-)}$ & {$[1.42,1.47]$} & {$[0.43,0.48]$} & {$[-]$} \\
\hline & $\mathrm{IV}-\left(\pi_{t-1}, y_{t-1}\right)$ & $\begin{array}{l}1.46 \\
(0.02)\end{array}$ & $\begin{array}{l}0.46 \\
(0.03)\end{array}$ & $\overline{(-)}$ & {$[1.42,1.50]$} & {$[0.42,0.50]$} & {$[-]$} \\
\hline & $\mathrm{IV}-\left(\pi_{t-1}, \pi_{t-2}\right)$ & $\begin{array}{l}1.50 \\
(0.05)\end{array}$ & $\begin{array}{l}0.50 \\
(0.05)\end{array}$ & $\overline{(-)}$ & {$[1.43,1.58]$} & {$[0.42,0.58]$} & {$[-]$} \\
\hline \multirow{3}{*}{ Backward-looking } & OLS & $\begin{array}{l}1.50 \\
(0.01)\end{array}$ & $\begin{array}{l}0.50 \\
(0.02)\end{array}$ & $\overline{(-)}$ & {$[1.48,1.51]$} & {$[0.46,0.53]$} & {$[-]$} \\
\hline & $\mathrm{IV}-\left(\pi_{t-1}, y_{t-1}\right)$ & $\begin{array}{l}1.50 \\
(0.01)\end{array}$ & $\begin{array}{l}0.50 \\
(0.02)\end{array}$ & $\frac{-}{(-)}$ & {$[1.48,1.51]$} & {$[0.46,0.54]$} & {$[-]$} \\
\hline & $\mathrm{IV}-\left(\pi_{t-1}, \pi_{t-2}\right)$ & $\begin{array}{l}1.50 \\
(0.01) \\
\end{array}$ & $\begin{array}{l}0.50 \\
(0.04) \\
\end{array}$ & $(-)$ & {$[1.48,1.52]$} & {$[0.43,0.57]$} & {$[-]$} \\
\hline \multicolumn{8}{|c|}{ Serial correlation: Hildreth-Liu estimations } \\
\hline \multirow{3}{*}{ Forward-looking } & OLS & $\begin{array}{l}0.95 \\
(0.02)\end{array}$ & $\begin{array}{l}-0.05 \\
(0.02)\end{array}$ & $\begin{array}{l}0.35 \\
(0.05)\end{array}$ & {$[0.90,0.99]$} & {$[-0.09,-0.01]$} & {$[0.27,0.43]$} \\
\hline & $\operatorname{IV}-\left(\pi_{t-1}, y_{t-1}\right)$ & $\begin{array}{l}0.72 \\
(0.05)\end{array}$ & $\begin{array}{l}-0.28 \\
(0.05)\end{array}$ & $\begin{array}{l}0.00 \\
(0.08)\end{array}$ & {$[0.64,0.80]$} & {$[-0.36,-0.20]$} & {$[-0.11,0.12]$} \\
\hline & $\mathrm{IV}-\left(\pi_{t-1}, \pi_{t-2}\right)$ & $\begin{array}{l}0.81 \\
(5.54)\end{array}$ & $\begin{array}{l}-0.19 \\
(5.56)\end{array}$ & $\begin{array}{l}0.06 \\
(0.49)\end{array}$ & {$[-0.86,2.4]$} & {$[-1.87,1.38]$} & {$[-0.78,0.95]$} \\
\hline \multirow{3}{*}{ Hybrid } & OLS & $\begin{array}{l}1.45 \\
(0.01)\end{array}$ & $\begin{array}{l}0.44 \\
(0.01)\end{array}$ & $\begin{array}{l}0.49 \\
(0.04)\end{array}$ & {$[1.43,1.47]$} & {$[0.42,0.47]$} & {$[0.42,0.55]$} \\
\hline & $\mathrm{IV}-\left(\pi_{t-1}, y_{t-1}\right)$ & $\begin{array}{l}1.48 \\
(0.04)\end{array}$ & $\begin{array}{l}0.48 \\
(0.04)\end{array}$ & $\begin{array}{l}0.41 \\
(0.06)\end{array}$ & {$[1.41,1.53]$} & {$[0.41,0.53]$} & {$[0.31,0.51]$} \\
\hline & $\operatorname{IV}-\left(\pi_{t-1}, \pi_{t-2}\right)$ & $\begin{array}{l}1.49 \\
(0.07)\end{array}$ & $\begin{array}{l}0.49 \\
(0.07)\end{array}$ & $\begin{array}{l}0.39 \\
(0.11)\end{array}$ & {$[1.38,1.60]$} & {$[0.38,0.61]$} & {$[0.19,0.54]$} \\
\hline \multirow{3}{*}{ Backward-looking } & OLS & $\begin{array}{l}1.50 \\
(0.01)\end{array}$ & $\begin{array}{l}0.50 \\
(0.02)\end{array}$ & $\begin{array}{l}0.49 \\
(0.04)\end{array}$ & {$[1.49,1.52]$} & {$[0.47,0.54]$} & {$[0.42,0.55]$} \\
\hline & $\mathrm{IV}-\left(\pi_{t-1}, y_{t-1}\right)$ & $\begin{array}{l}1.50 \\
(0.01)\end{array}$ & $\begin{array}{l}0.50 \\
(0.03)\end{array}$ & $\begin{array}{l}0.49 \\
(0.04)\end{array}$ & {$[1.48,1.52]$} & {$[0.46,0.54]$} & {$[0.42,0.55]$} \\
\hline & $\mathrm{IV}-\left(\pi_{t-1}, \pi_{t-2}\right)$ & $\begin{array}{l}1.50 \\
(0.01) \\
\end{array}$ & $\begin{array}{l}0.50 \\
(0.03) \\
\end{array}$ & $\begin{array}{l}0.49 \\
(0.04) \\
\end{array}$ & {$[1.48,1.52]$} & {$[0.45,0.55]$} & {$[0.42,0.55]$} \\
\hline
\end{tabular}

